\title{
Carboxymethyllysine, an Advanced Glycation End-Product, Promotes the Invasion and Migration of Lung Cancer A549 Cells
}

\author{
Te-chun Hsia ${ }^{1,2}$, Mei-chin Yin ${ }^{3, ~ *, ~ Z h i-h o n g ~ W a n g ~}{ }^{3, *}$ \\ ${ }^{1}$ Department of Respiratory Therapy, China Medical University, Taichung City, Taiwan \\ ${ }^{2}$ Department of Internal Medicine, China Medical University Hospital, Taichung City, Taiwan \\ ${ }^{3}$ Department of Food Nutrition and Health Biotechnology, Asia University, Taichung City, Taiwan
}

Email address:

mcyin@hotmail.com.tw (Mei-chin Yin), rover_wang@hotmail.com (Zhi-hong Wang)

${ }^{*}$ Corresponding author

\section{To cite this article:}

Te-chun Hsia, Mei-chin Yin, Zhi-hong Wang. Carboxymethyllysine, an Advanced Glycation End-Product, Promotes the Invasion and Migration of Lung Cancer A549 Cells. Clinical Medicine Research. Vol. 6, No. 5, 2017, pp. 149-156. doi: 10.11648/j.cmr.20170605.11

Received: August 8, 2017; Accepted: September 7, 2017; Published: October 16, 2017

\begin{abstract}
Effects of carboxymethyllysine (CML), an advanced glycation end-product (AGE), at 1, 2, 4, 8 or 16 $\mu$ mol/1 upon invasion and migration of A549 cells, non-small cell lung cancer (NSCLC) cells, were investigated. Results showed that CML at used test doses did not affect A549 cell growth. However, CML at 4-16 $\mu \mathrm{mol} / 1$ enhanced both invasion and migration, and stimulated the release of reactive oxygen species, interleukin-6 and tumor necrosis factor-alpha in A549 cells. CML at 2-16 $\mu \mathrm{mol} / 1$ increased protein expression of AGE receptor, $\mathrm{p} 47^{\text {phox }}$, intercellular adhesion molecule-1, fibronectin, kappa-B (NF- $\mathrm{KB}$ ) p65 and p-p38 in A549 cells. CML only at 4-16 $\mu \mathrm{mol} / 1$ increased matrix metalloproteinase-2 expression in A549 cells. These findings indicated that CML might benefit NSCLC metastasis through promoting invasion and migration.
\end{abstract}

Keywords: Carboxymethyllysine, Advanced Glycation End Products, NSCLC, A549 Cell, Migration, Invasion

\section{Introduction}

Carboxymethyllysine (CML) is an advanced glycation end-product (AGE). CML and other AGEs could be detected in many processed foods including canned meats, nuts or grain products [1]. It is reported that the intake of foods rich in AGEs increased AGEs content in circulation of patients with diabetes or chronic kidney disease [2, 3]. So far, the impact of AGEs upon cancer progression has attracted more attention because AGE level in tumors was markedly increased [4]. It is indicated that AGEs could engage with their receptor (RAGE), and the engagement in turn enhanced RAGE protein expression, and activated p38 mitogen-activated protein kinase (MAPK) and nuclear factor kappa-B (NF-kB) signaling pathways [5].

It is known that the activation of p38MAPK and NF- $\kappa B$ pathways induced the over-production of inflammatory, oxidative and/or metastatic molecules including tumor necrosis factor (TNF)-alpha, reactive oxygen species (ROS), transforming growth factor (TGF)-beta1, intercellular adhesion molecule (ICAM)-1, fibronectin and matrix metalloproteinases (MMPs) in non-small cell lung cancer (NSCLC) cells [6, 7]. Clinical evidence indicated that higher levels of TGF-beta1, ICAM-1 or MMP-2 in lung tissue were positively correlated with poor prognosis of NSCLC patients $[8,9]$. In addition, $\mathrm{p} 47^{\text {phox }}$ and gp91 ${ }^{\text {phox }}$, two subunits of NADPH oxidase, play crucial roles in activating NADPH oxidase complex and increasing oxidative stress through stimulating ROS generation [10]. In fact, the protein expression of RAGE in lung tissue is constitutive [11]. The study of Takino et al. [12] revealed that RAGE was correlated with cancer malignancy, and glyceraldehyde-derived AGEs promoted both migration and invasion of A549 cells, human NSCLC cells via increasing ROS generation and activating Rac 1. Thus, the impact of AGEs, through reacting with RAGE, upon NSCLC progression seems worthy to be investigated. That is, it is possible that the presence of AGEs from diets or endogenous bio-synthesis might up-regulate RAGE expression and activate associated pathways, which 
consequently stimulate the formation of inflammatory, oxidative and/or metastatic factors, and finally facilitate NSCLC progression. Since CML is commonly presented in many foods [1], it might favor or facilitate NSCLC progression and deterioration if it promotes the growth, invasion and/or migration of NSCLC cells

A549 cell line has been widely applied for NSCLC researches $[12,13]$. In this current study, this cell line was also used to examine the effects of CML at different concentrations upon A549 cell proliferation, invasion and migration. The influence of CML upon protein expression of RAGE, $\mathrm{p} 47^{\text {phox }}$, gp91 ${ }^{\text {phox }}$, ICAM-1, fibronectin, MMP-2, NF- $\kappa$ B and p-p38 in A549 cells was also analyzed.

\section{Materials and Methods}

\subsection{Materials}

CML (95\%) was purchased from Cayman Chemical Co. (Ann Arbor, MI, USA). Plates, chemicals, medium and antibiotics required for cell culture were obtained from Difco Laboratory (Detroit, MI, USA). Human NSCLC A549 cell line was obtained from American Type Culture Collection (Rockville, MD, USA).

\subsection{Cell Culture}

A549 cells were routinely cultured in RPMI 1640 medium consisted of $10 \%$ fetal bovine serum (FBS), 100 units $/ \mathrm{ml}$ of penicillin or streptomycin $(\mathrm{pH} 7.4)$ at $37^{\circ} \mathrm{C}$ under $5 \% \mathrm{CO}_{2}$ condition. Cells were sub-cultured every week, and the medium for cell culture was refreshed every three days. Cell number was adjusted by phosphate buffer saline (PBS, pH 7.2) to $10^{5} / \mathrm{ml}$ for experiments. It is reported that plasma CML level in healthy people were lower than $0.49 \mu \mathrm{mol} / 1$ [14] However, plasma CML level in diabetic patients was in the range of $0.2-12.6 \mu \mathrm{mol} / 1$ [15]. Therefore, $\mathrm{CML}$ at $1,2,4,8$ and $16 \mu \mathrm{mol} / 1$ were used in this current study to examine the adverse effects and impact upon NSCLC. A549 cells were treated with $\mathrm{CML}$ at those concentrations for $18 \mathrm{hr}$ at $37^{\circ} \mathrm{C}$, which caused $95.7 \pm 1.7 \%$ incorporation of CML into cells. CML treated A549 cells were washed by PBS twice, and PBS was collected for CML analysis by a competitive ELISA kit (Roche Diagnostics, Penzberg, Germany). The left CML in A549 cells were considered as incorporated. In the preliminary experiments, it was found that 12,18 or $24 \mathrm{hr}$ incubation led to $65.1,95.7$ or $96.2 \%$ incorporation of CML. Consequently, $18 \mathrm{hr}$ incubation was further used for this present study. Control group did not contain CML.

\subsection{Cell Proliferation}

Cell growth was assayed by using an ELISA colorimetric assay kit (Roche Diagnostics, Indianapolis, IN, USA), and cell numbers were counted by a hemocytometer.

\subsection{Cell Invasion and Migration}

Cell invasion or migration was determined in transwell chamber by a matrigel-or fibronectin-coated polycarbonate filter, respectively. Briefly, A549 cells $\left(10^{5} / 100 \mu \mathrm{l}\right)$ were added into the upper chamber containing $150 \mu \mathrm{l}$ of serum-free medium and $0.66 \mathrm{ml}$ of RPMI 1640 media. FBS at $10 \%$ as a chemoattractant was added into the lower chamber. After incubating $6 \mathrm{hr}$ for migration, or $16 \mathrm{hr}$ for invasion at $37^{\circ} \mathrm{C}$, A549 cells left on the upper surface of the filter were cleaned by cotton swabs. Then, cells migrated or invaded to the lower surface of the filter were stained by a crystal violet at $0.2 \%$ in $10 \%$ ethanol. Four different areas of invasive or migratory A549 cells per well were photographed by a microscope to count the cell numbers. Data were expressed as a percentage of the control groups.

\subsection{Measurement of ROS, Interleukin (IL)-6, TNF-alpha and TGF-betal}

A549 cells were washed and re-suspended in RPMI 1640 medium. ROS level was analyzed by an oxidation sensitive dye, 2',7'-dichlorofluorescein diacetate. After incubating with this dye at $50 \mu \mathrm{mol} / 1$ for $30 \mathrm{~min}$, cells were washed twice by PBS. After centrifugation at $412 \mathrm{xg}$, cells were further dissolved in solution containing $1 \%$ Triton X-100. Fluorescence values were monitored at time 0 and $5 \mathrm{~min}$ by a fluorescence microplate reader with excitation and emission wavelengths set at 485 and $530 \mathrm{~nm}$. The difference in fluorescence values between time 0 and $5 \mathrm{~min}$ was defined as relative fluorescence unit (RFU). Results are shown as RFU/mg protein. The level of IL-6, TNF-alpha or TGF-beta1 in culture supernatant was quantified by ELISA assay kits (R\&D Systems, Minneapolis, MN, USA). Protein concentration was measured by a commercial kit purchased from Pierce Biotechnology Inc. (Rockford, IL, USA).

\subsection{Real Time Polymerase Chain Reaction for $m R N A$ Expression}

Trizol reagent (Invitrogen, Life Technologies, Carlsbad, CA, USA) was used to isolate total RNA. RNA at $1 \mu \mathrm{g}$ was applied to generate cDNA, which was further amplified by Taq DNA polymerase. PCR was processed in $50 \mu \mathrm{l}$ of reaction mixture consisted of $20 \mathrm{mM}$ Tris- $\mathrm{HCl}, 2.5 \mathrm{U}$ Taq DNA polymerase, 0.5 $\mathrm{mM}$ of each primer, $50 \mathrm{mM} \mathrm{KCl}, 200 \mathrm{mM}$ dNTP and $2.5 \mathrm{mM}$ $\mathrm{MgCl}_{2}$. The oligonucleotide primers are as follow: Bcl-2, forward, 5'-TGC GCT CAG CCC TGT G-3', reverse, 5'-GGT AGC GAC GAG AGA AGT CAT C-3'; Bax, forward, 5'-CAA GAA GCT GAG CGA GTG TCT-3', reverse, 5'-CAA TCA TCC TCT GCA GCT CCA TAT T-3'; GAPDH, forward, 5'-AGA GGC AGG GAT GTT CTG-3', reverse, 5'-GAC TCA TGA CCA CAG TCC ATG C-3'. cDNA was amplified under the conditions: $95^{\circ} \mathrm{C}$ for $1 \mathrm{~min}, 95^{\circ} \mathrm{C}$ for $30 \mathrm{~s}$, and $58^{\circ} \mathrm{C}$ for $30 \mathrm{~s}$. Glyceraldehyde-3-phosphate dehydrogenase (GAPDH) was the housekeeping gene, and 28 cycles were performed for GAPDH, and 40 cycles were performed for Bcl-2 and Bax. Generated fluorescence was further quantified by real-time sequence detection Taqman system (ABI Prism 7700, Perkin-Elmer Inc., Foster City, CA, USA), and mRNA level was expressed as percentage of control groups. 


\subsection{Western Blot Analyses}

A549 cells were homogenized in protease-inhibitor cocktail with $0.5 \%$ Triton X-100 (Sigma-Aldrich Chemical Co., St. Louis, MO, USA). Then, this homogenate was mixed with a buffer containing 2\% SDS, $60 \mathrm{mM}$ Tris- $\mathrm{HCl}$ and $2 \%$ $\beta$-mercaptoethanol ( $\mathrm{pH}$ 7.2), After boiling for $5 \mathrm{~min}$, protein sample at $40 \mu \mathrm{g}$ was applied to SDS-PAGE, and followed by transferring to a nitrocellulose membrane for $1 \mathrm{hr}$. After treated by a $5 \%$ skim milk for $1 \mathrm{hr}$, nitrocellulose membrane was further processed with monoclonal antibodies (Boehringer-Mannheim, Indianapolis, IN, USA) against RAGE (1:500), p47 ${ }^{\text {phox }}$, gp91 ${ }^{\text {phox }}$, VEGF, ICAM-1, MMP-2, fibronectin, NF- $\kappa \mathrm{B}(1: 1000)$ or p38MAPK $(1: 2000)$ at $4^{\circ} \mathrm{C}$ overnight. Then, sample was reacted with horseradish peroxidase-conjugated antibody for $3.5 \mathrm{hr}$. The produced bands were quantified against glyceraldehyde-3-phosphate dehydrogenase (GAPDH), a loading control.

\subsection{Assay for NF-кB p50/65 DNA Binding Activity}

Nuclei pellets of A549 cells were isolated, and re-suspended in a mixture composed of $1 \mathrm{mM}$ EDTA, $20 \mathrm{mM}$ HEPES, 25\% glycerol, $0.4 \mathrm{M} \mathrm{NaCl}$ and $1 \mathrm{mM}$ DTT. Protein concentration was determined by a kit purchased from Pierce Biotechnology Inc. (Rockford, IL, USA). NF- $\kappa$ B p50/65 DNA binding activity was measured by an assay kit obtained from Chemicon International Co. (Temecula, CA, USA). The binding of activated NF- $\kappa \mathrm{B}$ was detected by processing nuclei with a polyclonal antibody against NF- $\mathrm{kB}$ p50/p65, and followed by reacting with another antibody conjugated with horseradish peroxidase, and the substrate was 3,3',5,5'-tetramethylbenzidine. The absorbance at $450 \mathrm{~nm}$ was monitored, and data are expressed as optical density (OD)/mg protein.

\subsection{Statistical Analysis}

The effect of each measurement was analyzed from three different preparations $(n=3)$. Data were expressed as means \pm standard deviation (SD), and further processed by one-way analysis of variance (ANOVA), and the differences among means were determined by Fisher's Least Significance Difference Test with significance defined at $p<0.05$.

\section{Results}

\subsection{Effects of CML upon Proliferation, Invasion and Migration of A549 Cells}

As shown in Figures 1 and 2, CML treatments at used concentrations did not alter A549 cell proliferation, and did not change mRNA expression of Bcl-2 and Bax in A549 cells $(p>0.05)$. However, CML at $4-16 \mu \mathrm{mol} / 1$ promoted invasion and migration of A549 cells (Table $1, p<0.05$ ).

\subsection{Effects of CML upon Oxidative and Inflammatory Factors}

CML at 4-16 $\mu \mathrm{mol} / 1$ increased the level of ROS,
TNF-alpha, IL-6 and TGF-beta1 in A549 cells (Table 2, $p<0.05)$. CML at 4-16 $\mu \mathrm{mol} / 1$ enhanced RAGE and $\mathrm{p} 47^{\text {phox }}$ expression in A549 cells (Figure 3, $p<0.05$ ). CML treatments at used concentrations did not affect $\mathrm{gp} 91^{\text {phox }}$ protein expression in A549 cells ( $p>0.05)$.

\subsection{Effects of CML upon NF-אB and p38MAPK Pathways}

CML at 2-16 $\mu \mathrm{mol} / 1$ increased the protein expression of NF- $\kappa$ B p65 and p-p38 in A549 cells (Figure 4, $<<0.05$ ). As shown in Figure 5, CML treatments at 2-16 $\mu \mathrm{mol} / 1$ increased NF- $\kappa$ B p50/65 DNA binding activity in A549 cells $(p<0.05)$.

\subsection{Effects of CML upon VEGF, ICAM-1, Fibronectin and MMP-2 Expression}

CML at 2-16 $\mu \mathrm{mol} / 1$ increased ICAM-1 and fibronectin protein expression in A549 (Figure 6, $p<0.05$ ). CML treatments at $4-16 \mu \mathrm{mol} / \mathrm{l}$ up-regulated MMP-2 protein expression in A549 cells $(p<0.05)$. CML at these concentrations did not alter VEGF expression in A549 cells $(p>0.05)$.

\section{Discussion}

CML could be found in many high temperature processed foods [16]. It is reported that dietary consumption of AGEs rich foods led to increasing circulating AGEs level [3, 4]. Then, these AGEs in circulation might be able to react with lung cancer cells. In this current study, CML at used concentrations failed to change cell proliferation, and mRNA expression of Bcl-2 and Bax in A549 cells. These results implied that $\mathrm{CML}$ at those concentrations did not promote lung tumor growth. However, the data revealed that CML enhanced invasion and migration, increased protein expression of RAGE, $\mathrm{p} 47^{\text {phox }}$ and several growth factors, and activated NF- $\mathrm{BB}$ and $\mathrm{p} 38 \mathrm{MAPK}$ pathways in A549 cells. These findings suggested that CML might be able to facilitate NSCLC metastasis. Ko et al. [17] indicated that AGEs favored invasion and migration of oral cancer cells. Takino et al. [14] reported that glyceraldehyde-derived AGEs benefited the migration of A549 cells. This present study agreed that the impact of AGEs upon cancer progression could not be ignored. Furthermore, the observed novel findings revealed that CML was a promotive agent for lung cancer cell metastasis. Therefore, NSCLC cancer patients should consider to limit dietary intake of AGEs rich foods in order to decrease RAGE protein expression, lower the interaction of RAGE and AGEs, and diminish the generation of factors associated with NSCLC metastasis.

Massive ROS production due to NADPH oxidase activation exacerbates lung tumorigenesis [18]. In this present study, CML substantially increased protein expression of $\mathrm{p} 47^{\text {phox }}$, a cytosolic subunit of NADPH oxidase, in A549 cells, which in turn stimulated ROS generation. TGF-beta1, a mediator responsible for inflammation and angiogenesis, causes cancer deterioration through facilitating epithelial-to-mesenchymal transition, especially in late stages [19]. Thus, the observed 
greater ROS and TGF-beta1 levels in CML treated A549 cells partially explained that CML raised oxidative, inflammatory and angiogenic stress in these NSCLC cells, which subsequently contributed to metastatic response of lung cancer. On the other hand, it is found that CML up-regulated protein expression of RAGE, p38MAPK and NF- $\mathrm{kB}$ in A549 cells. It is reported that the interaction of RAGE and AGEs could enhance RAGE expression, and activate NF- $\mathrm{kB}$ and MAPK signaling pathways [20]. However, the data revealed that $\mathrm{CML}$ at $4 \mu \mathrm{mol} / 1$ increased RAGE expression in A549 cells; but $\mathrm{CML}$ at $1 \mu \mathrm{mol} / 1$ promoted $\mathrm{p} 38$ phosphorylation, and at $2 \mu \mathrm{mol} / \mathrm{l}$ enhanced NF- $\mathrm{kB}$ p 65 expression in A549 cells These findings implied that CML could directly mediate NF- $\mathrm{kB}$ p 65 and p38MAPK expression. In addition, CML treatments raised NF- $\mathrm{KB}$ p50/65 DNA binding activity in A549 cells, which also supported the activation of NF- $\mathrm{kB}$ due to the stimulation from CML. The activation of NF- $\mathrm{kB}$ and p38MAPK pathways definitely facilitates the transcription of their downstream molecules including inflammatory cytokines and metastatic factors, which consequently benefits migration and invasion of lung cancer [21]. Since CML already activated RAGE, NF- $\mathrm{KB}$ and $\mathrm{p} 38 \mathrm{MAPK}$ pathways in A549 cells, the observed over-production of TNF-alpha and IL-6 in A549 cells could be explained.

ICAM-1 is a cell adhesion factor and involved in intercellular and extracellular matrix interactions of cancer cells [22], which contributes to cancer progression. Clinical evidence revealed that NSCLC patients had higher ICAM-1 level in circulation [23, 24], which was strongly correlated with poor prognosis and worse survival rate [23]. Fibronectin is a cellular matrix glycoprotein, and its expression is positively correlated with lung tumor growth and resistance to lung cancer therapy [25]. MMPs are responsible for the degradation of extracellular matrix components, which subsequently allows cancer cells to access and/or invade vascular or lymphatic systems and facilitate cancer metastasis [26]. MMP-2 has attracted more attention because it could degrade some basic components of the basement membrane in extracellular matrix such as type IV collagen [27]. In this present study, CML treatments substantially up-regulated the protein expression of ICAM-1, fibronectin and MMP-2 in A549 cells. Consequently, those metastatic factors contributed to the observed greater invasive and migratory capabilities of A549 cells. In addition, CML at used concentrations did not alter VEGF expression, a crucial element responsible for angiogenesis and cancer metastasis. These results suggested that CML might selectively affect some molecules to enhance the invasion and migration of A549 cells.

\section{Conclusion}

CML promoted both invasion and migration of A549 cells. CML increased protein expression of RAGE, $\mathrm{p} 47^{\text {phox }}, \mathrm{NF}-\kappa \mathrm{B}$ p65, p-p38, fibronectin, ICAM-1 and MMP-2 in A549 cells. These findings indicated that $\mathrm{CML}$ might benefit the metastasis of NSCLC.

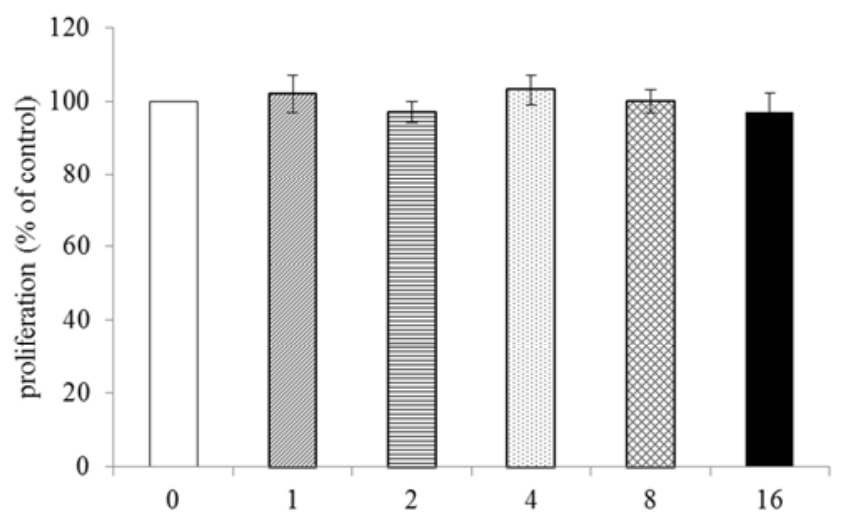

Figure 1. Effects of CML at 0 (control), 1, 2, 4, 8 or $16 \mu$ mol/l upon cell proliferation (\% of control) in human A549 cells. Cells were treated by CML for $18 \mathrm{hr}$ at $37^{\circ} \mathrm{C}$. Data are mean $\pm S D(n=3)$.

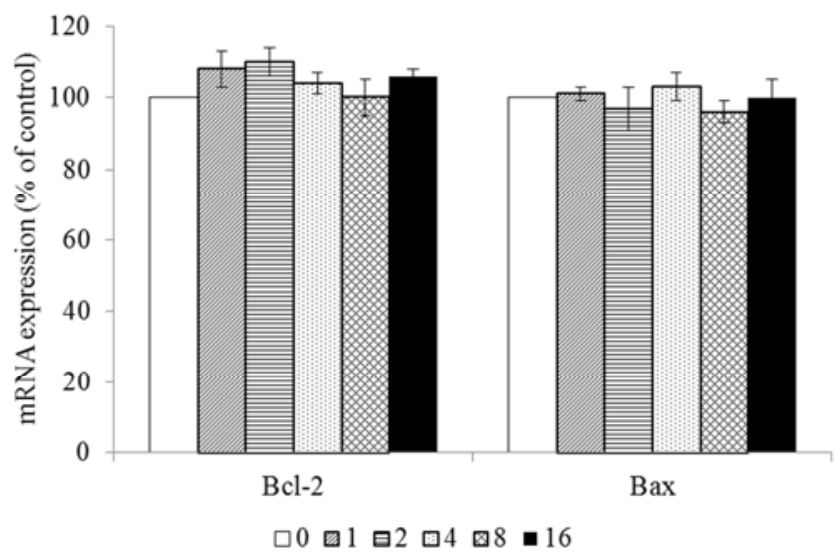

Figure 2. Effects of CML at 0 (control), 1, 2, 4, 8 or 16 بmol/l upon $m R N A$ expression (\% of control) of Bcl-2 and Bax in human A549 cells. Cells were treated by $C M L$ for $18 \mathrm{hr}$ at $37^{\circ} \mathrm{C}$. Data are mean $\pm S D(n=3)$.

Table 1. Effects of CML at 0 (control), 1, 2, 4, 8 or $16 \mu$ mol/l upon cell invasion (\% of control) and migration (\% of control) in human A549 cells. Cells were treated by $C M L$ for $18 \mathrm{hr}$ at $37^{\circ} \mathrm{C}$. Data are mean $\pm S D(n=3)$.

${ }^{a-c}$ Means within a column without a common letter differ, $p<0.05$.

\begin{tabular}{lll}
\hline & invasion & migration \\
\hline CML, 0 & $100^{\mathrm{a}}$ & $100^{\mathrm{a}}$ \\
1 & $104 \pm 7^{\mathrm{a}}$ & $102 \pm 3^{\mathrm{a}}$ \\
2 & $108 \pm 5^{\mathrm{a}}$ & $109 \pm 4^{\mathrm{a}}$ \\
4 & $131 \pm 6^{\mathrm{b}}$ & $138 \pm 8^{\mathrm{b}}$ \\
8 & $147 \pm 4^{\mathrm{b}}$ & $151 \pm 6^{\mathrm{b}}$ \\
16 & $170 \pm 8^{\mathrm{c}}$ & $178 \pm 5^{\mathrm{c}}$ \\
\hline
\end{tabular}

Table 2. Effects of CML at 0 (control), 1, 2, 4, 8 or $16 \mu$ mol/l upon ROS (RFU/mg protein), TNF-alpha (pg/mg protein), IL-6 (pg/mg protein) and TGF-betal (pg/mg protein) levels in human A549 cells. Cells were treated by $C M L$ for $18 \mathrm{hr}$ at $37^{\circ} \mathrm{C}$. Data are mean $\pm S D(n=3) .{ }^{a-d}$ Means within a column without a common letter differ, $p<0.05$.

\begin{tabular}{lllll}
\hline & ROS & TNF-alpha & IL-6 & TGF-beta1 \\
\hline CML, 0 & $1.76 \pm 0.15^{\mathrm{a}}$ & $143 \pm 10^{\mathrm{a}}$ & $126 \pm 8^{\mathrm{a}}$ & $154 \pm 16^{\mathrm{a}}$ \\
1 & $1.94 \pm 0.23^{\mathrm{a}}$ & $156 \pm 12^{\mathrm{a}}$ & $140 \pm 14^{\mathrm{a}}$ & $165 \pm 12^{\mathrm{a}}$ \\
2 & $2.08 \pm 0.19^{\mathrm{a}}$ & $170 \pm 15^{\mathrm{a}}$ & $145 \pm 17^{\mathrm{a}}$ & $172 \pm 8^{\mathrm{a}}$ \\
4 & $2.57 \pm 0.24^{\mathrm{b}}$ & $201 \pm 17^{\mathrm{b}}$ & $191 \pm 15^{\mathrm{b}}$ & $205 \pm 15^{\mathrm{b}}$ \\
8 & $2.71 \pm 0.25^{\mathrm{b}}$ & $242 \pm 19^{\mathrm{c}}$ & $232 \pm 12^{\mathrm{c}}$ & $251 \pm 18^{\mathrm{c}}$ \\
16 & $3.49 \pm 0.21^{\mathrm{c}}$ & $291 \pm 23^{\mathrm{d}}$ & $279 \pm 20^{\mathrm{d}}$ & $303 \pm 14^{\mathrm{d}}$ \\
\hline
\end{tabular}




\begin{tabular}{|c|c|c|c|c|c|c|}
\hline $\mathrm{CML}$ & 0 & 1 & 2 & 4 & 8 & 16 \\
\hline RAGE & $2=$ & sing & $m$ & 6ing & 6 & $m$ \\
\hline p47phox & & & & & & \\
\hline gp91phox & 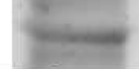 & $-\infty$ & 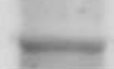 & 6 & $=$ & $=$ \\
\hline GAPDH & & & & & & \\
\hline
\end{tabular}

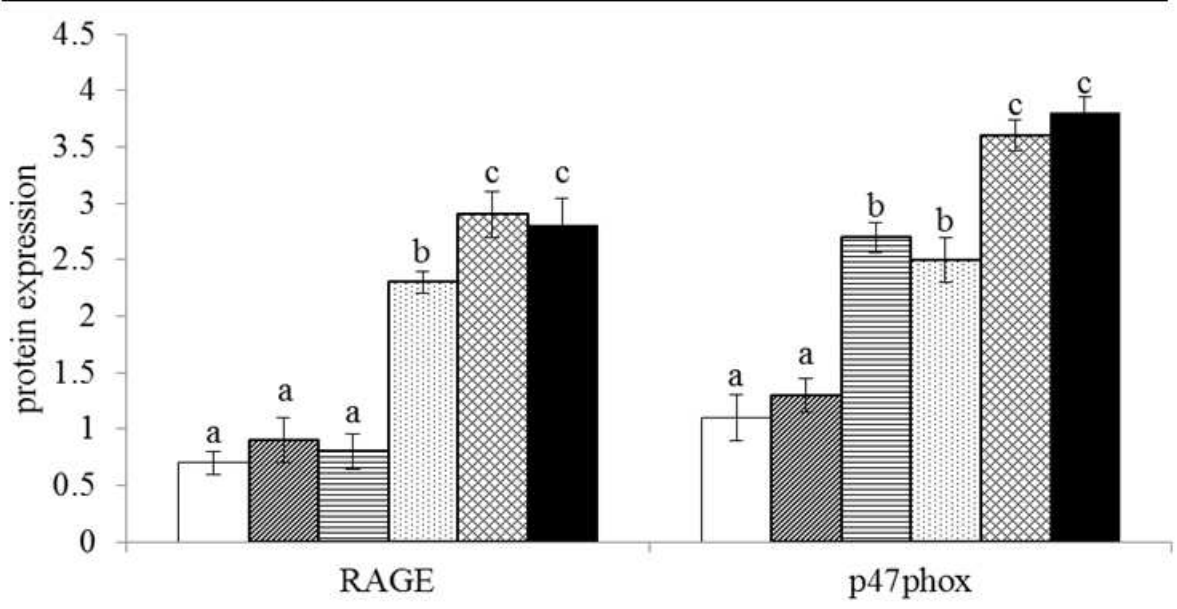

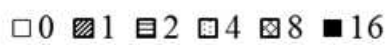

Figure 3. Effects of CML at 0 (control), 1, 2, 4, 8 or 16 umol/l upon protein expression of RAGE, $p 47^{p h o x}$ and gp $91^{\text {phox }}$ in human A549 cells. Cells were exposed to $C M L$ for $18 \mathrm{hr}$ at $37^{\circ} \mathrm{C}$. Data are mean $\pm S D(n=3) .{ }^{a-e}$ Means within a column without a common letter differ, $p<0.05$.

\begin{tabular}{|c|c|c|c|c|c|c|}
\hline CML & 0 & 1 & 2 & 4 & 8 & 16 \\
\hline $\mathrm{NF}-\kappa \mathrm{B}$ p50 & ments & 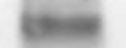 & 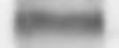 & $8=9$ & $\sin$ & 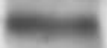 \\
\hline $\mathrm{NF}-\kappa \mathrm{B}$ p 65 & $=$ & 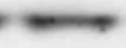 & 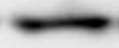 & - & $\rightarrow$ & $=$ \\
\hline p38 & coses & 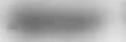 & 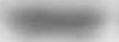 & $=$ & 5 & -2 \\
\hline p-p38 & 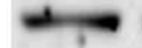 & $=$ & & & & \\
\hline GAPDH & 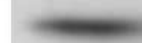 & sule & 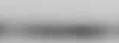 & 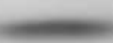 & 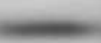 & $=$ \\
\hline
\end{tabular}

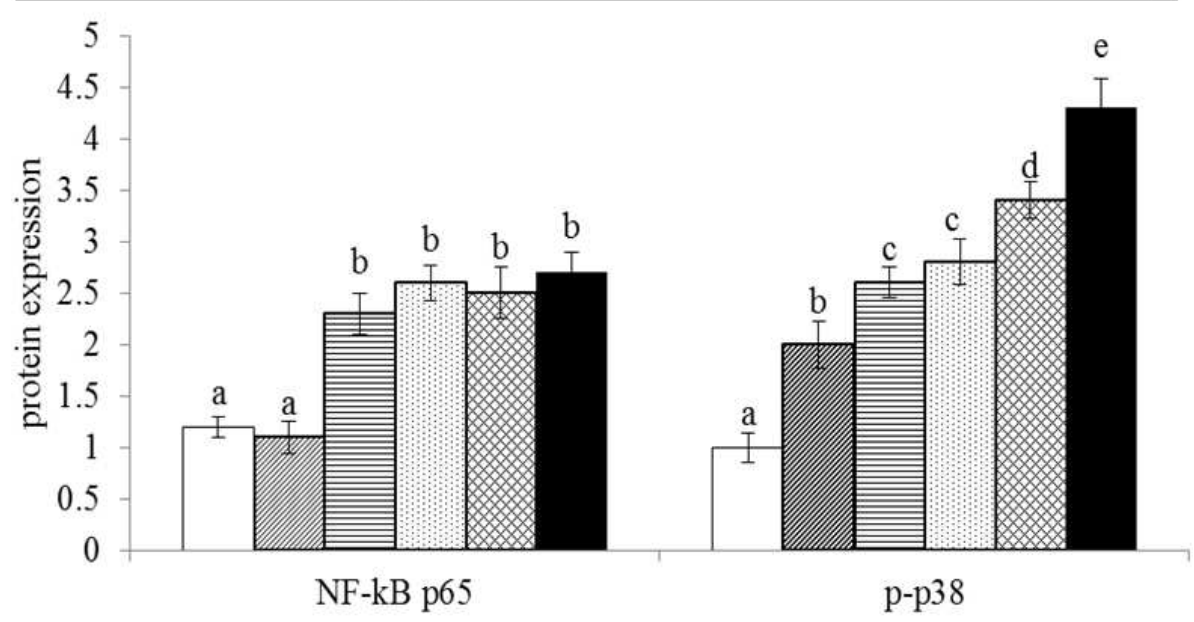

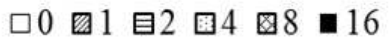

Figure 4. Effects of CML at 0 (control), 1, 2, 4, 8 or $16 \mu$ mol/l upon protein expression of NF- $\kappa B$ p 50, NF- $\kappa B$ p65, p38 and p-p38 in human A549 cells. Cells were exposed to CML for $18 \mathrm{hr}$ at $37^{\circ} \mathrm{C}$. Data are mean $\pm S D(n=3)$. ${ }^{a-e}$ Means within a column without a common letter differ, $p<0.05$. 


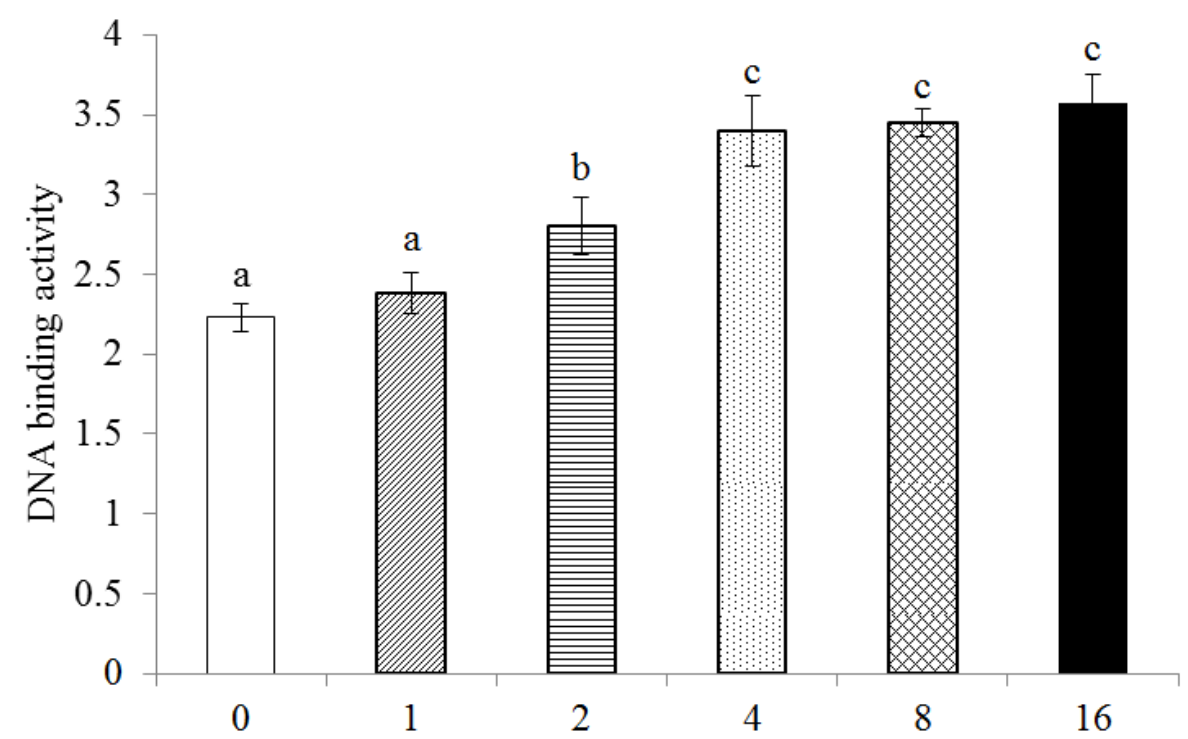

Figure 5. Effects of CML at 0 (control), 1, 2, 4, 8 or $16 \mu$ mol/l upon $N F-\kappa B$ p50/65 DNA binding activity in human A549 cells. Cells were exposed to CML for 18 hr at $37^{\circ} \mathrm{C}$. Data are mean $\pm S D(n=3) .{ }^{a-c}$ Means among bars without a common letter differ, $p<0.05$.

\begin{tabular}{|c|c|c|c|c|c|c|}
\hline CML & 0 & 1 & 2 & 4 & 8 & 16 \\
\hline VEGF & $=$ & & 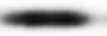 & as & - & $=$ \\
\hline ICAM-1 & 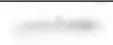 & - & $=$ & $=$ & $=$ & - \\
\hline fibronecti & & & & & & \\
\hline MMP-2 & $6=$ & $=$ & & & & \\
\hline GAPDH & 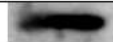 & $\rightarrow$ & $\rightarrow$ & $\infty$ & $\longrightarrow$ & $\infty$ \\
\hline
\end{tabular}

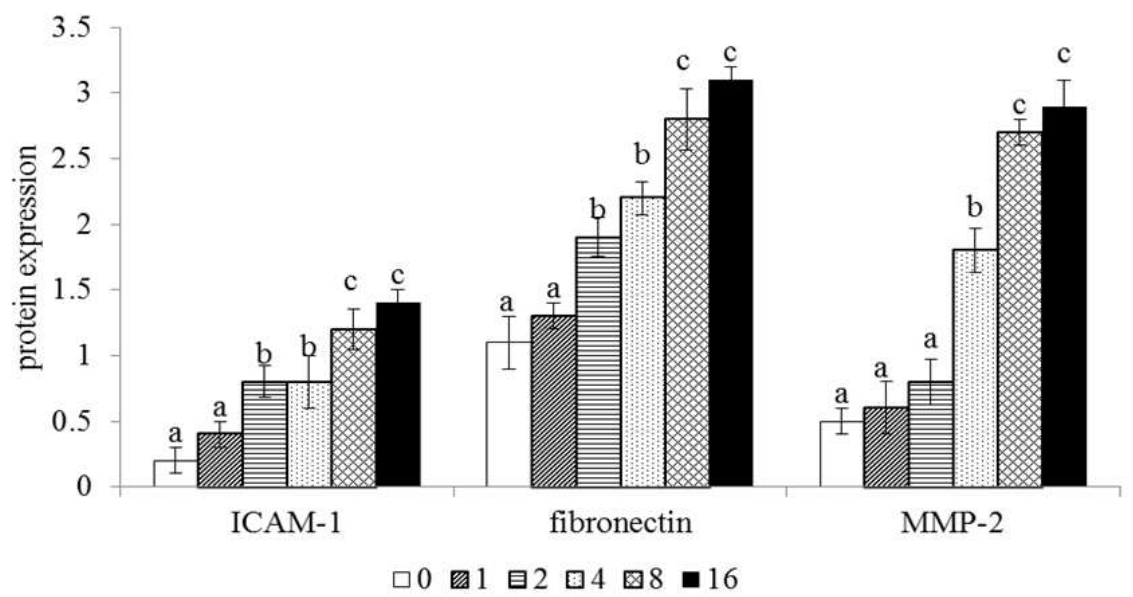

Figure 6. Effects of CML at 0 (control), 1, 2, 4, 8 or 16 umol/l upon protein expression of VEGF, ICAM-1, fibronectin and MMP-2 in human A549 cells. Cells were exposed to $C M L$ for $18 \mathrm{hr}$ at $37^{\circ} \mathrm{C}$. Data are mean $\pm S D(n=3) .{ }^{\text {a-e }}$ Means within a column without a common letter differ, $p<0.05$.

\section{Acknowledgements}

This study was supported by a grant from China Medical University, Taichung City, Taiwan (CMU105-ASIA-12).

\section{Author Contributions}

Hsia $\mathrm{TC}$ and Yin $\mathrm{MC}$ designed the experiments, Yin MC and Wang ZH performed the experiments. Hsia TC discussed the data. Yin MC and Wang ZH wrote the manuscript.

\section{Conflict of Interest}

The authors declare that they have no competing interests.

\section{Abbreviations}

The following abbreviations are used: 


$\begin{array}{ll}\text { CML } & \text { carboxymethyllysine } \\ \text { AGE } & \text { advanced glycation end-product } \\ \text { NSCLC } & \text { non-small cell lung cancer } \\ \text { MMP } & \text { matrix metalloproteinase } \\ \text { RAGE } & \text { receptor for advanced glycation end-product } \\ \text { MAPK } & \text { mitogen-activated protein kinase } \\ \text { NF- } \mathrm{BB} & \text { nuclear factor kappa-B } \\ \text { ROS } & \text { reactive oxygen species } \\ \text { TNF } & \text { tumor necrosis factor } \\ \text { ICAM } & \text { intercellular adhesion molecule } \\ \text { TGF } & \text { transforming growth factor } \\ \text { VEGF } & \text { vascular endothelial growth factor }\end{array}$

\section{References}

[1] Scheijen, J. L., Clevers, E., Engelen, L., Dagnelie, P. C., Brouns, F., Stehouwer, C. D. \& Schalkwijk, C. G. (2016). Analysis of advanced glycation endproducts in selected food items by ultra-performance liquid chromatography tandem mass spectrometry: Presentation of a dietary AGE database. Food Chemistry, 190, 1145-1150.

[2] Chao, P. C., Huang, C. N., Hsu, C. C., Yin, M. C. \& Guo, Y. R. (2010). Association of dietary AGEs with circulating AGEs, glycated LDL, IL-1 $\alpha$ and MCP-1 levels in type 2 diabetic patients. European Journal of Nutrition, 49, 429-434.

[3] Piroddi, M., Palazzetti, I., Quintaliani, G., Pilolli, F., Montaldi, M., Valentina, V., Libetta, C. \& Galli, F. (2011). Circulating levels and dietary intake of the advanced glycation end-product marker carboxymethyl lysine in chronic kidney disease patients on conservative predialysis therapy: a pilot study. Journal of Renal Nutrition, 21, 329-339.

[4] Turner, D. P. (2015). Advanced glycation end-products: a biological consequence of lifestyle contributing to cancer disparity. Cancer Research, 75, 1925-1929.

[5] Kim, J. Y., Park, H. K., Yoon, J. S., Kim, S. J., Kim, E. S., Ahn, K. S., Kim, D. S., Yoon, S. S., Kim, B. K. \& Lee, Y. Y. (2008). Advanced glycation end product (AGE)-induced proliferation of HEL cells via receptor for AGE-related signal pathways. International Journal of Oncology, 33, 493-501.

[6] Weng, Y., Cai, M., Zhu, J., Geng, J., Zhu, K., Jin, X. \& Ding, W. (2013). Matrix metalloproteinase activity in early-stage lung cancer. Onkologie, 36, 256-259.

[7] Tsao, S. M., Hsia, T. C. \& Yin, M. C. (2014). Protocatechuic acid inhibits lung cancer cells by modulating FAK, MAPK, and NF-кB pathways. Nutrition \& Cancer, 66, 1331-1341.

[8] Kumar, S., Guleria, R., Mohan, A., Singh, V., Bharti, A. C. \& Das, B. C. (2011). Efficacy of plasma TGF- $\beta 1$ level in predicting therapeutic efficacy and prognosis in patients with advanced non-small cell lung cancer. Cancer Investigation, 29, 202-207.

[9] Kanoh, Y., Abe, T., Masuda, N. \& Akahoshi, T. (2013). Progression of non-small cell lung cancer: diagnostic and prognostic utility of matrix metalloproteinase-2, C-reactive protein and serum amyloid A. Oncology Report, 29, 469-473.

[10] Liu, X., Pei, C., Yan, S., Liu, G., Liu, G., Chen, W., Cui, Y. \& Liu, Y. (2015). NADPH oxidase 1-dependent ROS is crucial for TLR4 signaling to promote tumor metastasis of non-small cell lung cancer. Tumour Biology, 36, 1493-1502.
[11] Marinakis, E., Bagkos, G., Piperi, C., Roussou, P. \& Diamanti-Kandarakis, E. (2014). Critical role of RAGE in lung physiology and tumorigenesis: a potential target of therapeutic intervention? Clinical Chemistry and Laboratory Medicine, 52, 189-200.

[12] Takino, J., Yamagishi, S. \& Takeuchi, M. (2010). Cancer malignancy is enhanced by glyceraldehyde-derived advanced glycation end-products. Journal of Oncology, 2010, 739852.

[13] Feng, H. T., Zhao, W. W., Lu, J. J., Wang, Y. T. \& Chen XP. (2017). Hypaconitine inhibits TGF- $\beta 1$-induced epithelial-mesenchymal transition and suppresses adhesion, migration, and invasion of lung cancer A549 cells. Chinese Journal of Natural Medicines, 15, 427-435.

[14] Hoonhorst, S. J., Lo Tam Loi, A. T., Pouwels, S. D., Faiz, A., Telenga, E. D., van den Berge, M., Koenderman, L., Lammers, J. W., Boezen, H. M., van Oosterhout, A. J., Lodewijk, M. E., Timens, W., Postma, D. S. \& Ten Hacken, N. H. (2016). Advanced glycation endproducts and their receptor in different body compartments in COPD. Respiratory Research, 17, 46.

[15] Misselwitz, J., Franke, S., Kauf, E., John, U. \& Stein, G. (2002). Advanced glycation end products in children with chronic renal failure and type 1 diabetes. Pediatric Nephrology, 17, 316-321.

[16] Chen, G. \& Smith, J. S. (2015). Determination of advanced glycation endproducts in cooked meat products. Food Chemistry, 68, 190-195.

[17] Ko, S. Y., Ko, H. A., Shieh, T. M., Chang, W. C., Chen, H. I., Chang, S. S. \& Lin, I. H. (2014). Cell migration is regulated by AGE-RAGE interaction in human oral cancer cells in vitro. PLoS One, 9, e110542.

[18] Valavanidis, A., Vlachogianni, T., Fiotakis, K. \& Loridas, S. (2013). Pulmonary oxidative stress, inflammation and cancer: respirable particulate matter, fibrous dusts and ozone as major causes of lung carcinogenesis through reactive oxygen species mechanisms. International Journal of Environmental Research and Public Health, 10, 3886-3907.

[19] Kumar, S., Guleria, R., Mohan, A., Singh, V., Bharti, A. C. \& Das, B. C. (2011). Efficacy of plasma TGF- $\beta 1$ level in predicting therapeutic efficacy and prognosis in patients with advanced non-small cell lung cancer. Cancer Investigation, 29, 202-207.

[20] Xie, J., Méndez, J. D., Méndez-Valenzuela, V. \& Aguilar-Hernández, M. M. (2013). Cellular signalling of the receptor for advanced glycation end products (RAGE). Cellular Signalling, 25, 2185-2197.

[21] Mehta, H. J., Patel, V. \& Sadikot, R. T. (2014). Curcumin and lung cancer-a review. Target Oncology, 9, 295-310.

[22] Gho, Y. S., Kim, P. N., Li, H. C., Elkin, M. \& Kleinman, H. K. (2001). Stimulation of tumor growth by human soluble intercellular adhesion molecule-1. Cancer Research, 61, 4253-4257.

[23] Dowlati, A., Gray, R., Sandler, A. B., Schiller, J. H. \& Johnson, D. H. (2008). Cell adhesion molecules, vascular endothelial growth factor, and basic fibroblast growth factor in patients with non-small cell lung cancer treated with chemotherapy with or without bevacizumab-an Eastern Cooperative Oncology Group Study. Clinical Cancer Research, 14, 1407-1412. 
[24] Guney, N., Soydinc, H. O., Derin, D., Tas, F., Camlica, H., Duranyildiz, D., Yasasever, V. \& Topuz, E. (2008). Serum levels of intercellular adhesion molecule ICAM-1 and E-selectin in advanced stage non-small cell lung cancer. Medical Oncology, 25, 194-200.

[25] Ritzenthaler, J. D., Han, S. \& Roman, J. (2008). Stimulation of lung carcinoma cell growth by fibronectin-integrin signaling. Molecular Bio Systems, 4, 1160-1169.
[26] Kanoh, Y., Abe, T., Masuda, N. \& Akahoshi, T. (2013). Progression of non-small cell lung cancer: diagnostic and prognostic utility of matrix metalloproteinase-2, C-reactive protein and serum amyloid A. Oncology Report, 29, 469-473.

[27] Pritchard, S. C., Nicolson, M. C., Lloret, C., McKay, J. A., Ross, V. G., Kerr, K. M., Murray, G. I. \& McLeod, H. L. (2001) Expression of matrix metalloproteinases 1,2,9 and their tissue inhibitors in stage II non-small cell lung cancer: implications for MMP inhibition therapy. Oncology Report, 8, 421-424. 